\title{
The battle of Brain vs. Heart: A literature review and meta-analysis of "hedonic motivation" use in UTAUT2
}

\section{Kuttimani Tamilmani}

Swansea University Bay Campus

School of Management

Fabian Way, Crymlyn Burrows

SWANSEA, SA1 8EN

Wales, UK

Email: kuttimani.tamilmani@gmail.com

\section{Nripendra P. Rana}

Emerging Markets Research Centre (EMaRC)

School of Management

Swansea University Bay Campus

Fabian Way, Crymlyn Burrows

SWANSEA, SA1 8EN, Wales, UK

Email: nrananp@gmail.com

Naveena Prakasam

School of Management

Swansea University Bay Campus

Fabian Way, Crymlyn Burrows

SWANSEA, SA1 8EN, Wales, UK

Email: n.prakasam@swansea.ac.uk

\section{Yogesh K. Dwivedi}

Emerging Markets Research Centre (EMaRC)

School of Management

Swansea University Bay Campus

Fabian Way, Crymlyn Burrows

SWANSEA, SA1 8EN

Wales, UK

Email: y.k.dwivedi@swansea.ac.uk

\begin{abstract}
Much of the scholarly debate on the extrinsic-intrinsic motivation dichotomy to date has focused on organisational context. However, the recent upsurge of technology use amongst individuals in non-organisational context has led to consumer-focused research model such as extended unified theory of acceptance and use of technology (UTAUT2). The objective of this study is to bring back much needed focus on motivation dichotomy from the consumer perspective. This involved a systematic review and meta-analysis of hedonic motivation an affective construct in UTAUT2 studies. The findings from 79 UTAUT2 empirical studies revealed that only 46 studies (58\%) utilised hedonic motivation while the remaining 33 studies $(42 \%)$ omitted the construct. Extrinsic motivation was the major driver of non-hedonic and non-significant hedonic motivation studies with individuals using technologies for utilitarian outcomes. Unlike UTAUT2, moderators association of hedonic motivation were nonsignificant in determining consumer intention to use technology. The findings also revealed an important association between hedonic motivation and effort expectancy, in addition to fruitful directions for research and practice.
\end{abstract}

Keywords: Meta-analysis, hedonic motivation, intrinsic motivation, UTAUT2, citation analysis 


\section{Introduction}

Information and Communication Technologies (ICT) were mostly available only to the organisational users of technology up until the end of the $20^{\text {th }}$ century. Extrinsic motivation was the primary driver of individual technology adoption in mandatory settings such as organisations in order to improve the performance of underlying task. Extrinsic motivation refers to performance of activities in order to achieve some objective distinct from the activity itself (Deci \& Ryan, 1980). Such instances of extrinsic motivation include but not limited to the use of smartphones to purchase goods and services through mobile commerce (Dwivedi et al., 2014) and accessing Internet to avail services such as e-government (e.g., Singh et al., 2017, 2019; Singh et al., 2018). In addition, individuals perform certain activity for the activity itself, to experience pleasure and satisfaction inherent to the activity. This second type of motivation is termed as intrinsic motivation (Deci \& Ryan, 1980). The popular technology acceptance research models such as: Davis's (1989) technology acceptance model (TAM) and Venkatesh et al.'s (2003) unified theory of acceptance and use of technology (UTAUT) found perceived usefulness/performance expectancy attribute to explain most of the variance in individual technology adoption decision. Perceived usefulness explains "the degree to which a person believes that using a particular system would enhance his or her job performance" (Davis, 1989, p.320). This underscores the dominant paradigm of extrinsic motivation in individual technology acceptance research.

The $21^{\text {st }}$ century witnessed unprecedented growth of mobile phone adoption with 5 billion unique mobile subscribers in 2017; mobile phones became the highest scale of consumer technology representing two thirds of the global population (Gsmaintelligence, 2017). This rapid explosion of mobile phones in combination with wider Internet penetration took ICT that was mostly available only to organisational users in the previous century to consumers. Notwithstanding the productive use of technologies, hedonic use of technologies started to gain prominence such as playing computer games, streaming music, and instant messaging to name a few (Hampton-Sosa, 2017; Makki et al., 2018; Venkatesh \& Brown, 2001). In line with emerging technology users, Venkatesh et al. (2012) extended the UTAUT model to consumer context with three new constructs: hedonic motivation, price value, and habit emphasising on hedonic value (intrinsic motivation) of consumers. Despite its recent introduction in 2012, UTAUT2 has already garnered more than 3,000 citations in Google Scholar alone spanning from information systems (IS) field and beyond emphasising on its predictive ability (Tamilmani et al., 2018a).

Hedonic motivation is considered as the most important theoretical addition to the UTAUT2 as it integrated the much-needed affective component into largely cognition based UTAUT. It shifted the focus from extrinsic motivation of organisational users to intrinsic motivation of consumer technologies. "Hedonic motivation" is defined as the fun or pleasure derived from using technology and it is an important determinant of consumer's technology acceptance and use (Alalwan, 2018; Baabdullah et al., 2019; Brown \& Venkatesh, 2005; Hamari \& Koivisto, 2015; Shareef et al., 2017; Shaw \& Sergueeva, 2019). This study represents hedonic motivation as an umbrella term to include similar constructs such as: hedonic expectancy (Ahn et al., 2016), perceived enjoyment ( e.g., Anandarajan et al., 2002; Gao et al., 2015a), and perceived playfulness (Robin et al., 2016) in UTAUT2 based studies. However, previous research found the scarce use of UTAUT2 model on its entirety with a rare inclusion of moderators in the research model. Meta-analysis on UTAUT2 based empirical studies found that only $41 \%$ studies included price value and a meagre 35\% studies included habit in their research often yielding inconsistent results (see Tamilmani et al., 2018c; 2018d). Hedonic motivation is not an exception to this trend; while hedonic motivation was found to be a significant predicator of mobile TV (Wong et al., 2014) and Instagram (Järvinen et al., 2016), it was found to be a 
non-significant predictor of mobile payments (Oliveira et al., 2016; Slade et al., 2015a). This is perennial problem in information systems (IS) discipline, as researchers often find inconsistent results for the same research question (i.e. understanding individual technology adoption). IS discipline is not alone in facing this research problem, other mature research streams such as social sciences reported similar inconsistencies. However, in comparison to social and behavioural sciences; IS researchers scarcely employ meta-analysis - a quantitative literature synthesis technique used in mature research streams for knowledge accumulation through integration of results from findings of previous studies (Glass, 1976; King \& He, 2005). In addition to meta-analysis, researchers have also employed weight-analysis and systematic literature review techniques for literature synthesis in the past ( e.g., Ismagilova et al., 2017; Kapoor et al., 2017; Tamilmani et al., 2018e; 2018b; Williams et al., 2015).

The preceding discussion underscores the centrality of three major things. First, UTAUT2 as most comprehensive theory in understanding individual technology adoption and use. Second, hedonic motivation as an important theoretical addition to UTAUT2 shifting the focus from extrinsic motivation as a dominant paradigm of technology adoption research to intrinsic motivation. Third, meta-analysis technique as a tool to shed light on operationalisation of established theoretical models through collation, analysis and synthesis of existing research findings. Our extant literature review suggests, existing research on the dichotomous nature of motivation (extrinsic and intrinsic) focused on the explanation of predictive ability of constructs perceived usefulness/performance expectancy and perceived/hedonic enjoyment in their research (Davis et al., 1992; Van der Heijden, 2004) or proposed a new model integrating the elements of affect and cognition (Kulviwat et al., 2007). However, none of these studies conducted meta-analysis to synthesise the existing literature to provide boundary conditions on the usage of hedonic motivation construct. Thus, the aim of this study is to fulfil this research gap and conduct a meta-analysis of studies that have used UTAUT2's additional constructs in their research. In doing so, this study attempts to understand the various associations of hedonic motivation attribute, their significance and non-significance to provide suitable boundary conditions for future researchers on operationalisation of the construct. In order to fulfil the objective of the study, it is necessary to undertake following steps:

- Locate studies that used UTAUT2 model as the underpinning theory and excluded hedonic motivation in their research model and reason for exclusion.

- Identify various antecedents and dependant variables of hedonic motivation to evaluate their significance and non-significance.

- Conduct meta-analysis of the empirical studies to understand the convergence and divergence of various hedonic motivation related relationships and their performance.

The remaining sections of this paper are structured as follows: The following Section 2 reviews existing research on hedonic motivation concerning individual technology adoption. Section 3 describes the research method employed leading to the meta-analysis and narrative review of UTAUT2 empirical studies in Section 4. The subsequent section (i.e. Section 5) presents discussion, implications for theory and practice. Finally, the paper ends with conclusion, limitations and future research directions in Section 6.

\section{Related work}

Researchers found motivation of individuals to perform an activity was of dichotomous nature namely extrinsic and intrinsic motivation (Deci \& Ryan, 1980; Vallerand, 1997). During the early stages of computer evolution, the scholarly debate in IS discipline was mostly focused on the extrinsic motivation of individuals and their intention to use computer tools for productivity gains. However, intrinsic motivation found itself a role in technology acceptance when Carroll 
and Thomas (1988), found fun/enjoyment as key underlying factor in user acceptance of Macintosh operated Apple Lisa computer. This claim was consistent with industry survey finding that found Macintosh computers to be rated more enjoyable to use than MS-DOS computers (Inc, 1988). Research of Davis et al. (1992) on two application such as: word processing software and business graphic program was the first exhaustive study to examine the effects of usefulness and enjoyment on computers usage in workplace. Their research found that the effect of usefulness was approximately four to five times greater in determining user intentions for both applications. In addition, the study found a positive interaction effect between enjoyment and usefulness. The results suggest that making the system more enjoyable would increase the level of acceptance of systems that are perceived more useful/productive but will have less effect on acceptance of systems that are perceived less useful. In other words, the effect of enjoyment on user acceptance of system is high for system with high-perceived usefulness and vice-versa (Davis et al., 1992).

The role of perceived usefulness as dominant predictor of information systems acceptance is not universal. Researchers have reported numerous expectations to this pattern where perceived enjoyment and ease of use played dominant role in user acceptance of information systems in home or leisure environment, games and game-based training of work-related environment diminishing the role of perceived usefulness. The research of Van der Heijden (2004) aimed to demonstrate this phenomenon of differences in user acceptance of technology between productivity-oriented and pleasure oriented information systems in non-work environment. He argued while the dominant design objective of a utilitarian system was productive use; the objective of hedonic system is to encourage prolonged use. The reason being, perceived usefulness plays prominent role in utilitarian systems than ease of system use, as system interaction is subordinate to achievement of external goals. Whereas, in hedonic systems, achievement of external goals is subordinate to the system interaction, making the role of ease of system use more central than perceived usefulness. Based on the preceding discussion, for hedonic systems Van der Heijden (2004) hypothesised perceived enjoyment and perceived ease of use as stronger predictors of behavioural intention to use a system than perceived usefulness. His study on 1,144 Dutch movie website users found both perceived enjoyment and perceived ease of use to have twice as much as predictive power in explaining consumer intention to use the websites than perceived usefulness. This research underscores the role of hedonic information systems as an important boundary condition in technology acceptance arena.

\section{Research method}

This study deemed an integrated approach of "narrative review", "citation reference search" and "meta-analysis" as appropriate to synthesise research findings from UTAUT2 based studies ( e.g., Dwivedi et al,, 2017; King \& He, 2006; Venkatesh et al., 2016; Zhao et al., 2017). Meta-analysis is an advanced form of secondary analysis that enables researchers to establish true effect size of various path relationships through advanced statistical techniques. It facilitates discovery of new knowledge from otherwise undetectable isolated parcels of data scattered amongst individual "primary" studies (Dwivedi et al., 2017; Field, 2001; Grinstein, 2008; Schmidt, 1992; Wu \& Du, 2012). Researchers conduct meta-analysis usually on either a fixed effects basis or random effects basis. The "fixed effect" meta-analysis model considers effect size to be as is for all studies in the population representing a "homogenous" case. In contrast, "random effects" basis considers individual studies in meta-analysis as part of large population of studies on a given topic. "Random effect" models for meta-analysis is preferred over "fixed effect" models as the later overstate the degree of precision in meta-analysis findings (Hunter \& Schmidt, 2000). Moreover, the random effect model allows researchers to make generalization about the research domain as a whole without restricting the findings only to studies involved in meta-analysis and considered more realistic (Field, 2001). This study 
employed random effect model of meta-analysis based on the above discussion for its advantages over the fixed-effect model.

\subsection{Sample}

This study employed cited reference search for Venkatesh et al.'s (2012) article in Scopus and Web of Science databases to locate studies needed for the meta-analysis. The search conducted from March 2012 to March 2017 period returned 1,320 results in total (823 from Scopus; 497 from Web of Science). On further inspection, the study found that 452 citations were common between both databases resulting in 868 unique citations. The next step involved checking for fully downloadable articles reducing the number to 650 . Out of 650 studies, a meagre 147 utilized at least one UTAUT2 additional construct; the remaining 503 articles just citied UTAUT2 for generic reasons (see Tamilmani et al., 2017 for review). The flowchart in Figure 1 depicts systematic process followed to arrive at final studies needed for meta-analysis. 


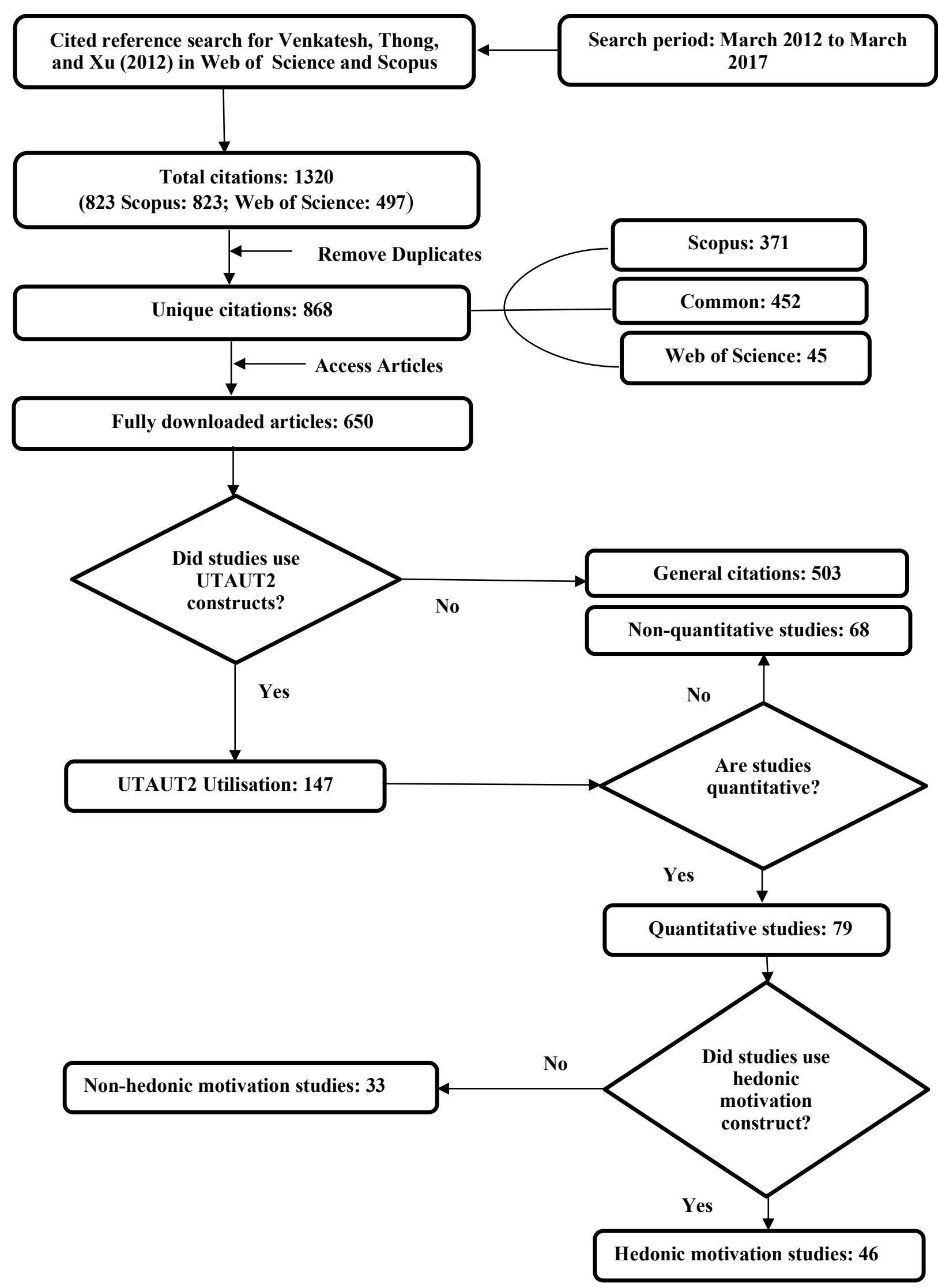

Figure 1: Systematic review flowchart 


\subsection{Coding}

The selection of the final studies for meta-analysis from the pool of 147 involved deployment of standardized coding rules. In order to be eligible for meta-analysis the studies have to fulfil the following three major criteria: First, they are UTAUT2 based quantitative empirical studies employing at least one UTAUT2 additional construct; Second, studies should have reported correlation matrix with Pearson correlation (r) or other statistics that may be converted to Pearson correlation (r) (see Wu \& Lederer, 2009), and finally, the studies should have reported data for sample size and the path coefficients (standardized) $(\beta)$ for their various path relationships (King \& He, 2006; Rana et al., 2015). In order to ensure only unique studies are included for meta-analysis, data from each study was checked to avoid duplication of studies using the same data for articles and conference proceedings. In cases where researchers used the same data for more than one study, only one study was included for final analysis (Ma \& Liu, 2004; Wu \& Du, 2012). On the other hand, if researchers reported multiple datasets in the same study, each of the datasets were included for analysis and treated as an independent study. This method of treatment is appropriate and does not violate any assumptions of meta-analysis (Hunter et al., 1982; Wu \& Du, 2012). The implementation of rules found only 79 studies were eligible to perform meta-analysis out of 147 studies. The remaining 68 studies are discarded from the scope of this research as they were neither empirical in nature nor did they report relevant data for meta-analysis.

\subsection{Analysis}

The process started with screening of 79 UTAUT2 based empirical studies to check the inclusion of 'hedonic motivation' construct in their research model. This resulted in the classification of 79 UTAUT2 studies broadly into two categories. The first category, "nonhedonic motivation studies" comprised of 33 studies that excluded hedonic motivation construct to include other UTAUT2 additional constructs such as price value or/and habit in their research model. The remaining 46 studies used hedonic motivation construct to form the second category, hedonic motivation studies and qualified for meta-analysis. This study conducted meta-analysis on "random effect basis" using comprehensive software downloaded from the www.meta-analysis.com website. The underlying assumption was that the individual studies were random samples taken from population with varying effect sizes such that the overall results is generalizable across the domain. In doing so, meta-analysis assumptions have incorporated both within-study and between study variance to provide more conservative significance test result (King \& He, 2006). Finally, this study performed meta-analysis on the collected data to determine cumulative value of path coefficients $(\beta)$ for various antecedents and dependent variables of hedonic motivation to determine significance and effect size of various path relationships.

\section{Findings}

The following sections present findings from literature synthesis and meta-analysis on both non-hedonic motivation (33 studies) and hedonic motivation (46 studies) categories.

\subsection{Review of non-hedonic motivation studies}

The non-hedonic motivation studies category comprising 33 studies constitute $42 \%$ of the total 79 UTAUT2 studies that excluded hedonic motivation in their research model. In terms of outcome variables, behavioral intention (BI) was the most operated construct representing 23 non-hedonic motivation studies encompassing $70 \%$. Use behaviour emerged as the distant second most operated outcome variable of non-hedonic motivation category representing 
meagre $18 \%$ with just six studies. The remaining four non-hedonic motivation studies comprising 12\% employed new outcome variables such as: 1) Consumerisation (CN) of IT (Dernbecher et al., 2013), 2) Location disclosure on location based social networking applications (Koohikamali et al., 2015), 3) Disclosure of information about others in social network sites (Koohikamali et al., 2017) and 4) Job seeker unemployment duration (Huang \& Chuang, 2016).

The next stage-involved classification of 33 non-hedonic motivation studies into seven major themes based on three parameters: type of technology examined, task performed and motivation type of users in performing their activity. Financial technologies (Fintech) emerged as the topmost research theme representing 10 studies as depicted in Appendix A. Fintech refers to the design and delivery of financial products though technology (Leong et al., 2017; Martins et al., 2014). Mobile payments with six examinations under Fintech theme emerged as the most examined technology type across all seven themes. The next five themes with their corresponding number of examinations are as follows: 1) User generated communities (UGC) - five studies, 2) Mobile technologies - four studies, 3) Education - three studies, 4) Egovernment, and 5) Entertainment two studies each. The final theme "others" comprised of seven studies that could not be readily classified under any of the above six categories with instances ranging from consumer use of biometric e-gates in airports (Morosan, 2016) to developers software reuse adoption (Cvijikj et al., 2015) to name a few.

Users performed 15 unique tasks while accessing range of technologies across the 33 nonhedonic motivation studies. Users "Conducting financial transactions" for various banking activities spread across ten studies emerged as the most performed task. "Content creation and sharing" in social networking sites/communities became the second most performed task with five studies. Users of three studies performed "service interactions" to emerge as the third popular task. The fourth position was jointly shared by three tasks such as: "listening to music", "accessing government services", and "learning" with two examinations each. Finally there were nine other tasks such as "commuting", "reading" and "searching for jobs" to name a few that were performed on one instance each as depicted in Appendix A. In terms of motivation of individuals to perform various tasks extrinsic motivation emerged as the major driver among 24 non-hedonic motivation studies comprising staggering $73 \%$ with just the remaining nine studies constituting $27 \%$ driven by intrinsic motivation.

\subsection{Reason for studies not using hedonic motivation}

This section presents the findings and plausible explanation for the 33 studies that adapted UTAUT2 as underpinning theory, however excluded hedonic motivation construct from their final research model in detail along with instances of quotes from actual studies in italics. Four categories emerged as reason for studies that excluded hedonic motivation construct from their research model as depicted in Table 1.

\subsubsection{Use of alternate model}

Kourouthanassis et al. (2015) in their pursuit to study effect of tourist's emotional states towards adoption of mobile augmented reality travel guides excluded hedonic motivation and integrated UTAUT2 with Pleasure, Arousal and Dominance (PAD) model.

\subsubsection{Recommended for future use}

Qasim and Abu-Shanab (2016), in their quest to explore drivers of consumer mobile payment acceptance in Jordan recommended use of hedonic motivation in future research. The following reason is stated in their study: 
"...It is important also to consider the proposition of the UTAUT 2 in the Jordanian environment, which was proposed by Venkatesh et al. (2012) and included predictors like hedonic motivation, price value and habit" (Qasim \& Abu-Shanab, 2016, p. 1031)

\subsubsection{Out of scope}

Mahfuz et al.'s (2016) research on influence of cultural dimensions and website quality on consumer's mobile banking adoption excluded habit and hedonic motivation construct in their research model stating the following reason:

"In this study, author omitted hedonic motivation and habit from the conceptual mode due not directly related to the mobile banking adoption" (Mahfuz et al., 2016, p. 432)

\subsubsection{No reason}

The majority of non-hedonic motivation studies as much as 30 studies encompassing $91 \%$ excluded hedonic motivation from their research model without providing any reason. Thus making "No Reason" as the most popular category. Such instances include range of studies from consumers intention to adopt Internet banking (Chaouali et al., 2016) to teachers' participation in virtual communities (Nistor et al., 2014) to mention a few.

Table 1: Reason for studies not using hedonic motivation construct

\begin{tabular}{lclll}
\hline Category Type & Frequency & Description & Example Citation(s) \\
\hline $\begin{array}{l}\text { 1. Use of } \\
\text { alternative model }\end{array}$ & 1 & $\begin{array}{l}\text { This study employed pleasure, Kourouthanassis et al. (2015a) } \\
\text { arousal, Dominance model to } \\
\text { evaluate consumer's emotional } \\
\text { states holistically while performing } \\
\text { tasks enabled through technology. }\end{array}$ & \\
\hline $\begin{array}{l}\text { 2. Recommended } \\
\text { for future use }\end{array}$ & 1 & $\begin{array}{l}\text { This study recommended use of Qasim and Abu-Shanab } \\
\text { hedonic motivation construct in } \\
\text { future studies }\end{array}$ & $\begin{array}{l}\text { This study excluded hedonic } \\
\text { motivation since the researchers } \\
\text { deemed the construct is not related } \\
\text { to technology under investigation }\end{array}$ & \\
\hline 3. Out of scope & 1 & $\begin{array}{l}\text { These studies did not provide any } \\
\text { reason for excluding hedonic et al. (2014) } \\
\text { motivation construct from their } \\
\text { research model }\end{array}$ & \\
\hline 4. No reason & 30 & &
\end{tabular}

\subsection{Review of studies using hedonic motivation construct}

Forty-six studies included hedonic motivation construct from UTAUT2 in their research model comprising $58 \%$ of the total 79 UTAUT2 studies. Unlike majority of the non-hedonic motivation studies that hypothesized BI as outcome variable, in case of hedonic motivation studies; Use behavior (e.g. Alalwan et al., 2017; Raman \& Don, 2013) emerged as the most operationalized outcome variable with 25 examinations. Nevertheless, behavioral intention (e.g. Slade et al., 2015a; Wong et al., 2014) was not far behind with 20 studies employing BI as their outcome variable. In addition, BI acted as mediating variable of hedonic motivation to use behavior in all the 25 studies. The final hedonic motivation study Buettner (2016) introduced new outcome variable "Job offer success" for the first time to measure individuals" job search behavior in career oriented social networking sites. Table 2 summarizes the path relationships among various dependant, independent and moderating variables of 46 'hedonic motivation' studies along with their significance and non-significance. It also reveals that hedonic motivation not only served as an antecedent, but also got antecedents on its own serving as dependant variables on six instances. 


\subsubsection{Hedonic motivation as an antecedent}

Over the span of 46 studies, hedonic motivation served as an antecedent of 10 unique dependant variables in understanding individual adoption to range of technologies. It served mostly as antecedent of BI with 53 examinations. The number of examinations is greater than number of studies because on few instances, researchers collected data from three different countries (Bangladesh, USA and Canada) such as Dwivedi et al., (2016) to develop generalised adoption model for citizens' mobile health; On such instances each dataset was treated as separate examination for meta-analysis purpose. Out of 53 examinations, the path relationship HM $\rightarrow$ BI was found significant on 43 instances (e.g. Baptista et al., 2017; Baptista \& Oliveira, 2015) and non-significant on the remaining ten instances (Oliveira et al., 2016; Slade et al., 2015a). Hedonic motivation served as antecedent of performance expectancy (PE) on three instances (Alalwan et al., 2016; Koenig-Lewis, Marquet, Palmer, \& Zhao, 2015; Robin et al., 2016) and effort expectancy (EE) on two instances (Koenig-Lewis et al., 2015; Robin et al., 2016) making them second and third most popular dependant variables. Overall, the path relationships between $\mathrm{HM} \rightarrow \mathrm{PE}$ and $\mathrm{HM} \rightarrow \mathrm{EE}$ were significant on all the five instances.

Hedonic motivation served as an antecedent of seven variables on one instance each and found to be significant on all seven instances. The seven dependant variables are: 1) Use behaviour (Lallmahomed et al., 2013), 2) Habit (Herrero \& San Martín, 2017), 3) Price value (Alalwan et al., 2016), 4) Trust (Alalwan et al., 2015), 5) Subjective norm (Robin et al., 2016), 6) Perceived advantages (Escobar-Rodrguez et al., 2014) and 7) Perceived risk (Koenig-Lewis et al., 2015). The variables such as age, gender, experience, collectivism (COL) and long-term orientation (LTO) moderated the HM $\rightarrow$ BI path relationship in five different combinations. $\mathrm{HM} \rightarrow \mathrm{BI}$ (Gender) was the most examined moderator relationship with four examinations comprising equally two significant (Baptista et al., 2017; Ramantoko et al., 2015) and nonsignificant studies (Ramírez-Correa et al., 2014; Wong et al., 2014). Whereas, the second most examined moderator relationships $\mathrm{HM} \rightarrow \mathrm{BI}$ (Age) with three examinations was found significant only once (Baptista et al., 2017) and non-significant on other two instances (Ramantoko et al., 2015; Ramírez-Correa et al., 2014). The remaining three moderator relationships $\mathrm{HM} \rightarrow \mathrm{BI}$ (EXP) (Ramírez-Correa et al., 2014), $\mathrm{HM} \rightarrow \mathrm{BI}(\mathrm{COL})$ and $\mathrm{HM} \rightarrow \mathrm{BI}$ (LTO) (Lai et al., 2016) were all examined one instances each and together found to be nonsignificant on all three instances as depicted in Table 2.

In addition to the above, Lu et al. (2017) employed two variants of hedonic motivation such as disconfirmation of perceived enjoyment (DEN) and post usage perceived enjoyment (PUPEJ) to examine individuals continuance use of mobile applications. These two variants had four different path relationships in various combinations with satisfaction (SAT), attitude (ATT) and continuance intention (CIN). The four path relationships were found significant on two instances (PUPEJ $\rightarrow$ SAT; PUPEJ $\rightarrow$ ATT) and non-significant on the remaining two instances $(\mathrm{DEN} \rightarrow \mathrm{SAT}$; PUPEJ $\rightarrow \mathrm{CIN})$.

\subsubsection{Antecedents of Hedonic motivation}

Hedonic motivation, apart from serving as antecedent, got antecedents on its own. Six such antecedents of hedonic motivation are as follows: 1) Mobile skillfulness (MSK) (Wong et al., 2015a), 2) Effort expectancy (EE) (Herrero \& San Martín, 2017), 3) Disconfirmation of perceived enjoyment (DEN) (Lu et al., 2017), 4) Social influence (SI) (Koenig-Lewis et al., 2015), 5) Context awareness (CAW); and 6) Unobtrusiveness (UNO) (Segura \& Thiesse, 2015). These six constructs served as antecedents of hedonic motivation on one instance each and found to have significant relationship on all six instances. 
Table 2: Hedonic motivation path relationships summary

\begin{tabular}{|c|c|c|c|c|c|c|c|}
\hline SL & I.V. & D.V.(Mod) & Total & Sig & Example Citations(Sig) & $\begin{array}{l}\text { Non- } \\
\text { Sig }\end{array}$ & $\begin{array}{l}\text { Example citations(Non- } \\
\text { Sig) }\end{array}$ \\
\hline 1 & HM & $\mathrm{BI}$ & 53 & 43 & $\begin{array}{lcc}\text { Alalwan et al. } & \text { (2017); } \\
\text { Baptista and } & \text { Oliveira } \\
(2015) ; & \text { Wong et al. } \\
(2015 a) & & \end{array}$ & 10 & $\begin{array}{l}\text { Koenig-Lewis et } \\
\text { (2015); Oliveira et } \\
\text { (2016); Slade et } \\
(2015 \mathrm{a})\end{array}$ \\
\hline 2 & $\mathrm{HM}$ & $\mathrm{PE}$ & 3 & 3 & $\begin{array}{l}\text { Alalwan et al. (2016); } \\
\text { Koenig-Lewis et al. } \\
\text { (2015); Robin et al. (2016) }\end{array}$ & 0 & None \\
\hline 3 & $\mathrm{HM}$ & $\mathrm{EE}$ & 2 & 2 & $\begin{array}{l}\text { Koenig-Lewis et al. } \\
\text { (2015); Robin et al. (2016) }\end{array}$ & 0 & None \\
\hline 4 & HM & UB & 1 & 1 & Lallmahomed et al. (2013) & 0 & None \\
\hline 5 & HM & HA & 1 & 1 & $\begin{array}{l}\text { Herrero and San Martín } \\
\text { (2017) }\end{array}$ & 0 & None \\
\hline 6 & $\mathrm{HM}$ & PV & 1 & 1 & Alalwan et al. (2016) & 0 & None \\
\hline 7 & $\mathrm{HM}$ & TR & 1 & 1 & Alalwan et al. (2015) & 0 & None \\
\hline 8 & $\mathrm{HM}$ & SN & 1 & 1 & Robin et al. (2016) & 0 & None \\
\hline 9 & $\mathrm{HM}$ & PA & 1 & 1 & $\begin{array}{l}\text { Escobar-Rodríguez and } \\
\text { Carvajal-Trujillo (2014) }\end{array}$ & 0 & None \\
\hline 10 & $\mathrm{HM}$ & $\mathrm{PR}$ & 1 & 1 & Koenig-Lewis et al. (2015) & 0 & None \\
\hline 11 & $\mathrm{HM}$ & $\mathrm{BI}(\mathrm{GEN})$ & 4 & 2 & $\begin{array}{l}\text { Baptista et al. (2017); } \\
\text { Ramantoko et al. (2015) }\end{array}$ & 2 & 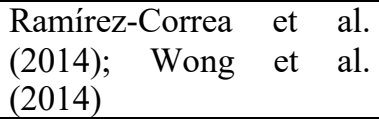 \\
\hline 12 & $\mathrm{HM}$ & $\mathrm{BI}(\mathrm{AGE})$ & 3 & 1 & Baptista et al. (2017) & 2 & $\begin{array}{l}\text { Ramírez-Correa et al. } \\
\text { (2014); Ramantoko et al. } \\
\text { (2015) }\end{array}$ \\
\hline 13 & HM & $\mathrm{BI}(\mathrm{EXP})$ & 1 & 0 & None & 1 & $\begin{array}{l}\text { Ramírez-Correa et al. } \\
(2014)\end{array}$ \\
\hline 14 & HM & $\mathrm{BI}(\mathrm{COL})$ & 1 & 0 & None & 1 & Lai et al. (2016) \\
\hline 15 & HM & $\mathrm{BI}(\mathrm{LTO})$ & 1 & 0 & None & 1 & Lai et al. (2016) \\
\hline 16 & DEN & SAT & 1 & 0 & None & 1 & Lu et al. (2017) \\
\hline 17 & PUPEJ & SAT & 1 & 1 & Lu et al. (2017) & 0 & None \\
\hline 18 & PUPEJ & ATT & 1 & 1 & Lu et al. (2017) & 0 & None \\
\hline 19 & PUPEJ & $\mathrm{CIN}$ & 1 & 0 & None & 1 & Lu et al. (2017) \\
\hline 20 & $\mathrm{UNO}$ & $\mathrm{HM}$ & 1 & 1 & Segura and Thiesse (2015) & 0 & None \\
\hline 21 & CAW & $\mathrm{HM}$ & 1 & 1 & Segura and Thiesse (2015) & 0 & None \\
\hline 22 & MSK & HM & 1 & 1 & Wong et al. (2015a) & 0 & None \\
\hline 23 & $\mathrm{EE}$ & $\mathrm{HM}$ & 1 & 1 & $\begin{array}{l}\text { Herrero and San Martín } \\
(2017)\end{array}$ & 0 & None \\
\hline 24 & DEN & PUPEJ & 1 & 1 & Lu et al. (2017) & 0 & None \\
\hline 25 & SI & HM & 1 & 1 & Koenig-Lewis et al. (2015) & 0 & None \\
\hline
\end{tabular}

[Legend: ATT: Attitude; BI: Behavioural Intention; CAW: Context Awareness; CIN: Continuance Intention; COL: Collectivism; LTO: Long-term Orientation; DEN: Disconfirmation of Perceived Enjoyment D.V.: Dependant Variable; EE: Effort Expectancy; Exp: Experience; Gen: Gender; HA: Habit; HM: Hedonic Motivation; I.V.: Independent Variable; Mod: Moderator; MSK: Mobile Skilfulness; Non-Sig: Number of nonsignificant path values; PA: Perceived Advantage; PE: Performance Expectancy; PR: Perceived Risk; PV: Price Value; PUPEJ: Post Usage Perceived Enjoyment; SAT: Satisfaction; Sig: Number of Significant Path Values; SL: Serial Number; SN: Subjective Norm; SI: Social Influence; TR: Trust; UB: Use Behaviour; UNO: Unobtrusiveness]

\subsection{Meta-analysis of studies using hedonic motivation construct}

Meta-analysis is increasingly preferred over traditional narrative assessment of literature review especially in mature research streams such as Information systems. Meta-analysis provides rigorous, unbiased, trustworthy interventions through clarification and synthesis of 
existing research findings including studies with non-significant and contradictory results to derive collective conclusion (Dwivedi et al., 2017; Eden, 2002; Sabherwal et al., 2006). This study conducted meta-analysis of various 'hedonic motivation' dependant, independent and moderating variables path relationships explored on two or more instance across 46 hedonic motivation studies (e.g., King \& He, 2006; Rana et al., 2015; Wu \& Du, 2012). Only five path relationships fulfilled this criterion of two or more examinations from a total of 25 unique 'hedonic motivation' path relationships depicted in Table 2. Three main (HM $\rightarrow \mathrm{BI}$; $\mathrm{HM} \rightarrow \mathrm{PE}$; $\mathrm{HM} \rightarrow \mathrm{EE})$ and two moderator $(\mathrm{HM} \rightarrow \mathrm{BI}($ Age $) /(\mathrm{Gen}))$ relationships constituted these five eligible paths of meta-analysis. Finally, this study subjected all five eligible path relationships analysis to meta-analysis using comprehensive meta-analysis software. Table 3 depicts the summary of results emerging from the analysis.

Table 3: Meta-analysis of 'hedonic motivation' path coefficients ( $\beta$ ) (Adapted from King \& He (2006))

\begin{tabular}{ccccccccc}
\hline SL & I.V. & D.V.(Mod) & $\#$ & TSS & p(ES) & Meta $(\boldsymbol{\beta})$ & $\mathbf{9 5 \%} \mathbf{L}(\boldsymbol{\beta})$ & $\mathbf{9 5 \%} \mathbf{H}(\boldsymbol{\beta})$ \\
\hline 1 & HM & BI & 53 & 19306 & 0.000 & 0.259 & 0.199 & 0.316 \\
2 & HM & PE & 3 & 1095 & 0.008 & 0.524 & 0.154 & 0.766 \\
3 & HM & EE & 2 & 772 & 0.000 & 0.687 & 0.591 & 0.764 \\
4 & HM & BI(Gen) & 4 & 1520 & 0.956 & 0.003 & -0.113 & 0.119 \\
5 & HM & BI(Age) & 3 & 1327 & 0.800 & -0.073 & -0.126 & -0.019 \\
\hline
\end{tabular}

[Legend: \#: Number of studies; BI: Behavioural Intention; D.V.: Dependant Variable; EE: Effort Expectancy; PE: Performance Expectancy; Gen: Gender; H $(\beta)$ : Highest (beta); I.V.: Independent Variable; L ( $\beta$ ): Lowest (Beta); Meta $(\beta)$ : Meta-analysis path coefficient; Mod: Moderator; p (ES): Estimated Value of p; TSS: Total Sample Size]

Meta-analysis results from Table 3 revealed only direct path relationships of HM such as: $\mathrm{HM} \rightarrow \mathrm{BI}, \mathrm{HM} \rightarrow \mathrm{PE}$, and $\mathrm{HM} \rightarrow \mathrm{EE}$ to be significant at $\mathrm{p}<0.05$ level. The remaining two moderator path relationships $\mathrm{HM} \rightarrow \mathrm{BI}$ (Gender) and $\mathrm{HM} \rightarrow \mathrm{BI}$ (Age) were non-significant with very high $p$ values of 0.956 and 0.800 respectively. In terms of significant paths, the impact of hedonic motivation was stronger on effort expectancy with $(\beta) 0.687$ than behavioural intention and Performance expectancy with ( $\beta$ ) 0.259 and $(\beta) 0.524$ respectively. In addition, while the $95 \%$ confidence interval of HM $\rightarrow$ EE path was wider with Low $(\beta)-0.591$ and High $(\beta)-$ 0.764 . The confidence interval for $\mathrm{HM} \rightarrow \mathrm{BI}$ was the narrowest with Low $(\beta)-0.199$ and High $(\beta)-0.316$ revealing the range is narrow enough to explain at least one confidence within the extent of variance.

\section{Discussion}

This study conducted a literature review and meta-analysis on 79 UTAUT2 empirical studies in the pursuit to understand and provide suitable conditions for hedonic motivation construct usage. The findings revealed $58 \%$ of UTAUT2 studies included hedonic motivation construct that is much higher in comparison to just $41 \%$ and $35 \%$ inclusion of two other UTAUT2 additional constructs price value and habit respectively in similar studies(see Tamilmani et al., 2018c; 2018d). The findings on individuals' motivation to perform various activities revealed that the primary driver behind vast majority of individuals as much as $73 \%$ in non-hedonic motivation-based studies was extrinsic motivation. These individuals performed activities such as "assessing e-government services", "conducting financial transactions" and "reading ebooks" to improve effectiveness of their task underscoring the utilitarian value that are distinct form the activity itself. Although the driver behind the remaining $23 \%$ non-hedonic motivation studies was intrinsic motivation that involves individuals performing task for end in itself such as "online content creation" and "music streaming" majority of these studies excluded hedonic motivation construct without providing any reason. Understandably 'no reason' emerged as the top category among non-hedonic motivation studies with 30 out of $33(91 \%)$ of them not providing any reason for exclusion. 
The path relationship $\mathrm{HM} \rightarrow \mathrm{BI}$ was the most examined path in hedonic motivation studies, comprising 43 significant and 10 non-significant examinations. Like non-hedonic motivation, the vast majority of non-significant $\mathrm{HM} \rightarrow \mathrm{BI}$ studies such as mobile payments and learning were driven through extrinsic motivation of individuals in order to improve the performance of the underlying task underscoring the utilitarian value. For instance, mobile payments (Koenig-Lewis et al., 2015; Oliveira et al., 2016; Slade et al., 2015a) enables individuals to conduct financial transaction anywhere, anytime saving enormous time and effort for them in comparison to visiting physical bank for conducting financial transactions. Likewise, learning management system (LMS) software (Ain et al., 2016) enabled students to remotely access course content, submit assignments, participate in discussion forum and downloading/uploading course related files saving their time. The above-mentioned scenarios illustrate tasks performed to improve the performance of an activity are extrinsically motived. Researchers should be cautious of involving hedonic motivation in situation where utilitarian outcomes completely outweighs the hedonic outcomes. In addition, this study found fascinating outcomes for hedonic motivation within a single study producing mixed results depending upon the contexts such as country and type of technology examined. For instance, hedonic motivation was a significant determinant of consumer intention towards fitness wearable devices but non-significant determinant of medical wearable devices. The plausible explanation for this pattern is medical wearable devices are regarded as life-saving and understandably consumer expectation on the performance expectancy is of paramount importance on such devices diminishing the role of hedonic expectancy (Gao et al., 2015b). In terms of countries as context, the research of Dwivedi et al. (2016) on citizen's use of mhealth in three different countries found hedonic motivation to be significant predictor only among Bangladeshi citizens and non-significant among citizens of other two countries USA, and Canada. The reason for this pattern could be citizens from countries with low Internet penetration such as Bangladesh experience fun while accessing technologies such as m-health over internet that are novel to them. This is not the case for citizens from developed countries such as: USA and Canada with wider internet penetration they are exposed to plethora of mobile applications on day today basis. Hence accessing $m$-health for citizens from developed countries is not as novel/fun in comparison to citizens from developing and under developed countries( Dwivedi et al., 2016).

Originally hedonic motivation was hypothesised only as an antecedent of BI in the UTAUT2 model with age, gender and experience as moderators. However, this study found the umbrella construct hedonic motivation to have 25 unique path relationships comprising of both dependent and antecedent variables as depicted in Table 2. It served as an antecedent of PE (three instances) and EE (two instances) - the two most dominant predictors of individual technology acceptance in popular information systems theories/models. Together the paths $\mathrm{HM} \rightarrow \mathrm{PE}$ and $\mathrm{HM} \rightarrow \mathrm{EE}$ are found significant on all the five instances validating the findings of Van der Heijden (2004) that suggest enjoyable technology are perceived more useful and easier to use. In addition to PE and EE, Table 2 reveals $\mathrm{HM}$ also served as a significant antecedent of eight other variables on at least one instance including BI. Furthermore, apart from being an antecedent, the findings divulge hedonic motivation also served as dependant variable on six instances. For example, two constructs such as: unobtrusiveness (UNO) (a pervasive measure of technological system becoming both cognitively and physically invisible to its users) and context awareness (an enabler for services to provide additional value such as Location based services) were found significant antecedents of hedonic motivation in determining consumer intention to use Google glass (Segura \& Thiesse, 2015).

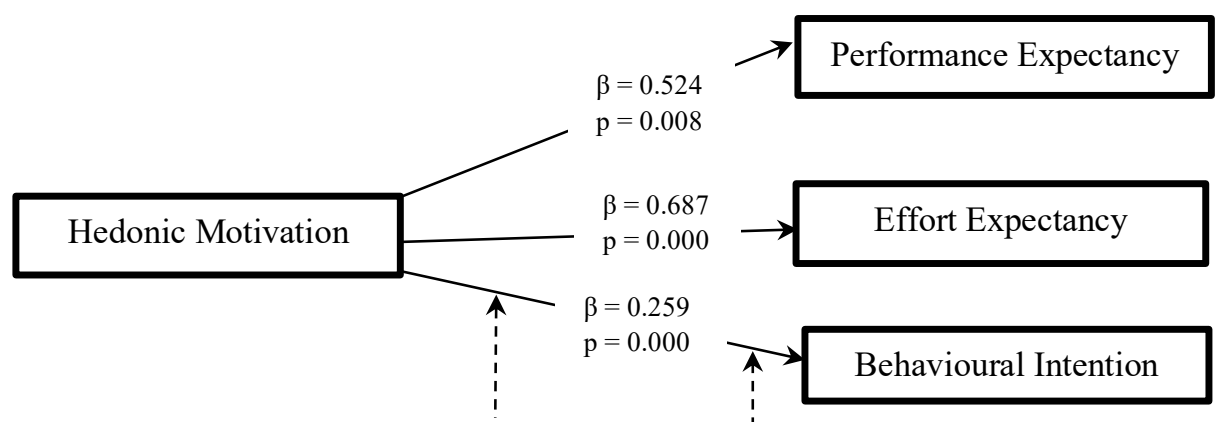


Fig 2: Resultant model of hedonic motivation meta-analysis

Figure 2 depicts model emerging from meta-analysis of "hedonic motivation" path relationships. The model divulges effect of moderators: gender and age are not significant enough to influence individual adoption of technologies driven by hedonic motivation. This is significant departure from Venkatesh et al.'s (2012) research on 1,512 Hong Kong mobile Internet users found age, gender, and experience to moderate the effect of hedonic motivation on behavioural intention such that effects were stronger for younger men in early stage of experience with product. In similar vein, Venkatesh et al.'s (2016, p.347) review of UTAUT based studies found disparity of moderator relationships and they excluded effects of moderators in their proposed multi-level framework to measure individual technology acceptance and use across various use contexts. In terms of direct associations, all three HM path relationships $\mathrm{HM} \rightarrow \mathrm{PE}, \mathrm{HM} \rightarrow \mathrm{BI}$, and $\mathrm{HM} \rightarrow \mathrm{EE}$ were significant at $\mathrm{p}<0.05$ level with $\mathrm{HM} \rightarrow \mathrm{EE}$ emerging as the strongest path relationship. Prior researchers has well established the role of hedonic motivation in predicting behavioural intention (Davis et al., 1992; Van der Heijden, 2004). On the contrary, while the majority of existing researchers have manipulated difficulty of task and examined its effect on intrinsic motivation making association from ease of use/effort expectancy to hedonic motivation (Van der Heijden, 2004), meta-analysis revealed change in locus of causality from hedonic motivation to effort expectancy. This change in locus of causality was not surprising, as research by Venkatesh (1999) found manipulating the system specific enjoyment through gamified training not only enhanced the ease of use but also increased salience of perceived ease of use as determinant of individual intention decision to use technology. In addition, the research by Venkatesh (2000) in the following year on determinants of perceived ease of use grounded on anchor and adjustment framework proposed two variants of intrinsic motivation: "computer playfulness" as a systemindependent individual difference anchor variable during early use of technology and "perceived enjoyment" as system-specific individual difference adjustment variable after gaining experience on interaction with technology. The study conducted on 246 system users at different times found both computer playfulness and perceived enjoyment as significant determinants of ease of use in early and later stage of system use respectively. To that extent, the meta-analysis finding of significant $\mathrm{HM} \rightarrow \mathrm{EE}$ path relationship is an important revelation for researchers in the technology adoption arena.

\subsection{Implications for theory and practice}

This first meta-analytic review on hedonic motivation offers several implications for researchers and practitioners alike. It provides three major contributions to the existing body of technology adoption literature, in particular on operationalisation of intrinsically driven hedonic motivation construct. First, unlike the UTAUT2 model, meta-analysis found the effect of moderators to be non-significant on $\mathrm{HM} \rightarrow \mathrm{BI}$ path relationship. Moderators' inclusion into UTAUT theories was a significant departure from its guiding theories such as TAM, TRA and 
TPB since none of them employed moderators in their model. Thus, moderators may not be universally applicable to all contexts and could run into the risk of being completely irrelevant in certain settings. Researchers should therefore exercise caution in including moderators in their study (Dwivedi et al., 2017). Second, this study found significant association between scarcely examined path relationships $\mathrm{HM} \rightarrow \mathrm{EE}$ underscoring the significance of intrinsic motivation as determinant of ease of use/effort expectancy. Third, this study propose a framework as depicted in Table 4 to serve as guideline for researchers on selection of hedonic motivation construct. This aims to avoid researcher's exclusion of hedonic motivation, whilst examining technologies driven by intrinsic motivation focussed on hedonic outcomes underscoring affective physiological behaviour and including them in technologies, driven by extrinsic motivation focussed on utilitarian outcomes underscoring cognitive physiological behaviour. The researchers should also provide sufficient explanation in case of omission of construct since this study found majority of studies did not reveal one. In addition, investigators should consider how people in developing and under-developed countries perceive novel utilitarian technologies as fun, which in turn could significantly determine their technology use (Dwivedi et al., 2016).

Table 4: Framework for hedonic motivation use

\begin{tabular}{ccc}
\hline Underlying concept & Hedonic motivation Significant $(\checkmark)$ & Hedonic motivation non-significant $(\times)$ \\
\hline Motivation & Intrinsic & Extrinsic \\
Outcome & Hedonic & Utilitarian \\
Psychology & Affective & Cognitive \\
\hline
\end{tabular}

The findings of this study provide several implications for practice. Besides motivation, the scholarly debate in IS has often focused on information systems success/failure dichotomy. The failure to implement information systems technologies can result in serious financial consequences for organisations ultimately generating huge losses (Dwivedi et al., 2015). In most of these cases, a major hurdle is individual finding the underlying system too difficult to interact with and hence difficult to use (Venkatesh, 2000). One of the salient findings of this study is significant association between hedonic motivation and effort expectancy/ease of use. Practitioners should exploit individual's intrinsic motivation in technology environments to leverage the association between $\mathrm{HM} \rightarrow \mathrm{EE}$ paths. Few such instances are as follows: introduction of "fun icons" in MS-Office 97, "warm and fuzzy" screen savers (e.g., flashing cartoons, favourite sport team, etc.), and gamified training interventions to break individuals monotony while engaging with various technologies to enhance acceptance of new systems (Venkatesh, 1999, 2000). Moreover, hedonic motivation is a strong significant direct predictor of individual intention to use technology. In cases of people rejecting utilitarian systems, to achieve user acceptance designers should consider invoking hedonic features of the system. This is similar to making bitter pills sweet on the outside to make it go down easily (Van der Heijden, 2004). In addition, practitioners should be cautious as hedonic motivation appeals to consumers only during early stage of product life cycle, once consumers start using the actual product and gain experience the utility parameters of products outweighs all other attributes (Venkatesh et al., 2012). This means even if organisations could acquire early adopters through novel hedonic product features in order to capture market share and thrive, they should offer compelling products that can efficiently improve/provide solution for consumer problems efficiently during later stages. Finally, in order to maximize the effects of hedonic motivation among consumer's organisations should leverage all of its six significant antecedents such as: Mobile skilfulness, effort expectancy (EE), Disconfirmation of perceived enjoyment, Social influence, Context awareness, and Unobtrusiveness.

\section{Conclusion}

This study brought much needed spotlight to the motivation dichotomy in technology adoption research from consumer perspective. This study evaluated hedonic motivation usage in 
UTAUT2 based studies through narrative literature review and meta-analysis. The findings revealed extrinsic motivation as the primary driver behind 24 non-hedonic motivation and ten non-significant hedonic motivation-based studies. Hence, hedonic motivation is not an appropriate construct in examining technologies where consumers engage in technology for utilitarian purposes such as improving their effectiveness or efficiency in performing various tasks. Moreover, meta-analysis results revealed effects of moderators to be non-significant for $\mathrm{HM} \rightarrow \mathrm{BI}$ path relationship. This was a significant departure from the original UTAUT2, researchers should be more cautious in future while operationalizing their constructs to make necessary adaptations or omit irrelevant constructs depending upon context rather than having obligation to replicate all the constructs in underpinning model/theory. However, hedonic motivation was the most used newly added UTAUT2 construct with $58 \%$ studies employing this construct in their research model. Majority of the hedonic motivation studies focused on the intrinsic motivation of users where consumer motivation for using technology was to derive fun or pleasure. Thus hedonic motivation is an appropriate construct for research focused on hedonic outcomes, where consumer performs task for the novelty and fun/pleasure derived from the activity.

\subsection{Limitations and future research directions}

Despite robust coding mechanisms and precautionary measures employed in the study to avoid methodological errors, readers should interpret findings from this study in light of following limitations. First, this study confined hedonic motivation usage only to UTAUT2 based empirical studies available from two databases (Web of Science and Scopus). In future, researchers should widen their search horizon to multiple databases without restricting to single theory such as UTAUT2. This will increase the number of articles available for meta-analysis leading to superior effect sizes. Second, this study limited the meta-analysis only to the path coefficients $(\beta)$. Although meta-analysis of path coefficients $(\beta)$ is a better measure to evaluate strength of path relationships, future researchers should employ correlation $(r)$ based analysis with robust statistical techniques to compute variance $\left(\mathrm{R}^{2}\right)$. This will lead to establish variance of hedonic motivation on its dependant variables and its antecedents. Third, meta-analysis technique is restricted to quantitative studies resulting in exclusion of studies using hedonic construct in qualitative setting. Future research should consider weight-analysis that allows inclusion of qualitative studies while evaluating strength between dependant and independent variable. Fourth, this study restricted meta-analysis to single UTAUT2 additional construct "hedonic motivation". Future studies should consider other UTAUT2 constructs for metaanalysis to compare and contrast the best predictor of technology adoption among UTAUT2 constructs. Finally, due to a smaller number of studies, we were not able to perform metaanalysis on hedonic motivation moderators and its antecedents that calls for exploration with large sample size in future.

Appendix A: Classification of studies not using Hedonic motivation construct

\begin{tabular}{|l|l|l|l|l|}
\hline SN & $\begin{array}{l}\text { Theme/Technology } \\
\text { examined (with frequency) }\end{array}$ & Task (with frequency) & $\begin{array}{l}\text { Motivation } \\
\text { Type (with } \\
\text { frequency) }\end{array}$ & Source(s) \\
\hline 1 & Fintech (10) & \multicolumn{3}{|l|}{} \\
\hline & Mobile Payments (6) & $\begin{array}{l}\text { Conducting financial } \\
\text { transactions (6) }\end{array}$ & Extrinsic (6) & $\begin{array}{l}\text { Jia et al. (2014); Jia et al. (2015); } \\
\text { Qasim and Abu-Shanab (2016); } \\
\text { Shaw (2014); Slade et al., } \\
(2015 b) ; \text { Teo et al. (2015b) }\end{array}$ \\
\hline & Internet banking (2) & $\begin{array}{l}\text { Conducting financial } \\
\text { transactions (2) }\end{array}$ & Extrinsic (2) & $\begin{array}{l}\text { Chaouali et al. (2016); Salim et } \\
\text { al. (2016) }\end{array}$ \\
\hline & $\begin{array}{l}\text { Financial products use on } \\
\text { internet }\end{array}$ & $\begin{array}{l}\text { Conducting financial } \\
\text { transactions (1) }\end{array}$ & Extrinsic (1) & Huang (2016) \\
\hline
\end{tabular}




\begin{tabular}{|c|c|c|c|c|}
\hline & Mobile banking & $\begin{array}{l}\text { Conducting financial } \\
\text { transactions (1) }\end{array}$ & Extrinsic (1) & Mahfuz et al. (2016) \\
\hline \multirow[t]{6}{*}{2} & \multicolumn{4}{|c|}{ User generated content (UGC) Communities (5) } \\
\hline & $\begin{array}{l}\text { Information sharing in SNS } \\
\text { (1) }\end{array}$ & $\begin{array}{l}\text { Content creation and } \\
\text { sharing (1) }\end{array}$ & Intrinsic (1) & Hajli and Lin (2016) \\
\hline & $\begin{array}{l}\text { Location disclosure on LB- } \\
\text { SNAs (1) }\end{array}$ & $\begin{array}{l}\text { Content creation and } \\
\text { sharing (1) }\end{array}$ & Intrinsic (1) & Koohikamali et al. (2015) \\
\hline & $\begin{array}{l}\text { Information disclosure in } \\
\text { SNS (1) }\end{array}$ & $\begin{array}{l}\text { Content creation and } \\
\text { sharing (1) }\end{array}$ & Intrinsic (1) & Koohikamali et al. (2017) \\
\hline & $\begin{array}{l}\text { Virtual communities of } \\
\text { practice }(\mathrm{VCoP})(1)\end{array}$ & $\begin{array}{l}\text { Content creation and } \\
\text { sharing (1) }\end{array}$ & Intrinsic (1) & Nistor et al. (2014) \\
\hline & $\begin{array}{l}\text { Online help seeking in } \\
\text { community of practice (1) }\end{array}$ & $\begin{array}{l}\text { Content creation and } \\
\text { sharing (1) }\end{array}$ & Intrinsic (1) & Nistor et al. (2012) \\
\hline \multirow[t]{5}{*}{3} & \multicolumn{4}{|l|}{ Mobile Technologies (4) } \\
\hline & $\begin{array}{l}\text { Mobile Augmented Reality } \\
\text { (MAR) }\end{array}$ & $\begin{array}{l}\text { Navigating using MAR } \\
\text { travel guide }\end{array}$ & Intrinsic (1) & Kourouthanassis et al. (2015b) \\
\hline & $\begin{array}{l}\text { Value co-creation in hotels } \\
\text { through mobile devices }\end{array}$ & Service interactions & Extrinsic (1) & Morosan and DeFranco (2016) \\
\hline & $\begin{array}{l}\text { Mobile devices in private } \\
\text { clubs }\end{array}$ & Service interactions & Extrinsic (1) & Morosan and DeFranco (2014) \\
\hline & $\begin{array}{l}\text { Interactive mobile } \\
\text { technologies (IMT) in hotels }\end{array}$ & Service interactions & Extrinsic (1) & Wendy Zhu and Morosan (2014) \\
\hline \multirow[t]{4}{*}{4} & \multicolumn{4}{|l|}{ Education (3) } \\
\hline & $\begin{array}{l}\text { Podcasting in higher } \\
\text { education (1) }\end{array}$ & Learning (1) & Extrinsic (1) & Lin et al. (2013) \\
\hline & Mobile learning (1) & Learning (1) & Extrinsic (1) & Wong et al. (2015b) \\
\hline & E-books (1) & Reading (1) & Extrinsic (1) & Yoo and Roh (2016) \\
\hline \multirow[t]{2}{*}{5} & \multicolumn{4}{|l|}{ E-government (2) } \\
\hline & Government to Citizens (2) & $\begin{array}{l}\text { Assessing government } \\
\text { services (2) }\end{array}$ & Extrinsic (2) & $\begin{array}{l}\text { Fakhoury and Aubert (2015); } \\
\text { Lallmahomed et al. (2017) }\end{array}$ \\
\hline \multirow[t]{2}{*}{6} & \multicolumn{4}{|l|}{ Entertainment (2) } \\
\hline & Music as a service (2) & Listening to music (2) & Intrinsic (2) & $\begin{array}{l}\text { Wagner et al. (2014); Wagner } \\
\text { and Hess (2013) }\end{array}$ \\
\hline \multirow[t]{8}{*}{7} & \multicolumn{4}{|l|}{ Others (7) } \\
\hline & crime-tracking IS & $\begin{array}{l}\text { Sharing crime related } \\
\text { information }\end{array}$ & Intrinsic (1) & Cvijikj et al. (2015) \\
\hline & Electric vehicles & Commuting & Extrinsic (1) & Degirmenci and Breitner (2017) \\
\hline & Consumerization of IT & $\begin{array}{l}\text { Using personal digital } \\
\text { devices for work }\end{array}$ & Extrinsic (1) & Dernbecher et al. (2013) \\
\hline & Biometric e-gates in airports & check in at Airports & Extrinsic (1) & Morosan (2016) \\
\hline & Broadband Technology Use & Using Internet & Extrinsic (1) & Muraina et al. (2016) \\
\hline & Software reuse adoption & Use of existing software & Extrinsic (1) & Stefi (2015) \\
\hline & Recruitment & Searching for Jobs & Extrinsic (1) & Huang and Chuang (2016) \\
\hline
\end{tabular}

Appendix B: Studies using Hedonic motivation construct

\begin{tabular}{|r|l|l|l|l|}
\hline $\begin{array}{l}\text { Study } \\
\text { Number }\end{array}$ & Source & Country & $\begin{array}{l}\text { Respondent } \\
\text { Type }\end{array}$ & Technology examined \\
\hline 1 & Ahn et al. (2016) & USA & Consumer & Household Technology \\
\hline 2 & Ain et al. (2016) & Malaysia & Student & Learning Management system \\
\hline 3 & Alalwan et al. (2015) & Jordon & Consumer & Internet Banking \\
\hline 4 & Alalwan et al. (2016) & Jordon & Consumer & Telebanking \\
\hline 5 & Alalwan et al. (2017) & Jordon & Consumer & Mobile Banking \\
\hline 6 & Ali et al. (2016) & Malaysia & Student & $\begin{array}{l}\text { Computer Supported } \\
\text { Classrooms }\end{array}$ \\
\hline 7 & An et al. (2016) & China & Students & $\begin{array}{l}\text { Online shopping of Agricultural } \\
\text { products }\end{array}$ \\
\hline 8 & $\begin{array}{l}\text { Baptista \& Oliveira } \\
(2015)\end{array}$ & Mozambique & Consumers & Mobile Banking \\
\hline
\end{tabular}




\begin{tabular}{|c|c|c|c|c|}
\hline 9 & $\begin{array}{l}\text { Baptista \& Oliveira } \\
\text { (2017) }\end{array}$ & Brazil & Consumers & $\begin{array}{l}\text { Gamification Impact on Mobile } \\
\text { Banking }\end{array}$ \\
\hline 10 & Bere (2014) & South Africa & Students & Mobile Learning \\
\hline 11 & Buettner (2016) & Germany & $\begin{array}{l}\text { Working } \\
\text { Professionals }\end{array}$ & $\begin{array}{l}\text { Job search in Social } \\
\text { Networking Sites }\end{array}$ \\
\hline 12 & Chong \& Ngai (2013) & China & Consumers & $\begin{array}{l}\text { Location based Social media } \\
\text { service }\end{array}$ \\
\hline \multirow[t]{3}{*}{13} & Dwivedi et al. (2016) & USA & Citizens & Mobile Health \\
\hline & Dwivedi et al. (2016) & Canada & Citizens & Mobile Health \\
\hline & Dwivedi et al. (2016) & Bangladesh & Citizens & Mobile Health \\
\hline 14 & $\begin{array}{l}\text { Escobar-Rodríguez \& } \\
\text { Carvajal-Trujillo } \\
\text { (2013) }\end{array}$ & Spain & Consumers & Website airline tickets \\
\hline 15 & $\begin{array}{l}\text { Escobar-Rodríguez \& } \\
\text { Carvajal-Trujillo } \\
\text { (2014) }\end{array}$ & Spain & Consumers & $\begin{array}{l}\text { Online purchasing tickets for } \\
\text { low cost carriers }\end{array}$ \\
\hline \multirow[t]{2}{*}{16} & Gao et al. (2015a) & China & $\begin{array}{l}\text { Middle Aged } \\
\text { Adults }\end{array}$ & Smart phone adoption \\
\hline & Gao et al. (2015a) & China & Older Adults & Smart phone adoption \\
\hline 17 & Gao et al. (2015c) & China & Consumers & Smart phone adoption \\
\hline \multirow[t]{3}{*}{18} & Gao et al. (2015b) & China & $\begin{array}{l}\text { General } \\
\text { Consumers }\end{array}$ & Wearable healthcare technology \\
\hline & Gao et al. (2015b) & China & $\begin{array}{l}\text { Fitness } \\
\text { sample }\end{array}$ & Wearable healthcare technology \\
\hline & Gao et al. (2015b) & China & $\begin{array}{l}\text { Medical } \\
\text { Sample }\end{array}$ & Wearable healthcare technology \\
\hline \multirow[t]{2}{*}{19} & Guo (2014) & China & $\begin{array}{l}\text { Male } \\
\text { Consumers }\end{array}$ & Mobile Social Networking Sites \\
\hline & Guo (2014) & China & $\begin{array}{l}\text { Female } \\
\text { Consumers }\end{array}$ & Mobile Social Networking Sites \\
\hline 20 & Herrero et al. (2017) & Spain & Consumers & $\begin{array}{l}\text { Sharing User Generated Content } \\
\text { in Social networking sites }\end{array}$ \\
\hline
\end{tabular}

Appendix B: Studies using Hedonic motivation construct

\begin{tabular}{|r|l|l|l|l|}
\hline $\begin{array}{l}\text { Study } \\
\text { Number }\end{array}$ & Source & Country & Respondent Type & Technology examined \\
\hline 21 & Hew et al. (2015) & Malaysia & Consumers & Mobile Apps \\
\hline 22 & Hsieh et al. (2014) & Taiwan & Smart Phone Users & Smart phone and tablets \\
\hline 23 & Hsieh et al. (2014) & Taiwan & Tablet Users & Smart phone and tablets \\
$(2016)$ & Europe & Consumers & Instagram (SNS) \\
\hline 24 & Jyoti et al. (2014) & $\begin{array}{l}\text { United } \\
\text { Kingdom }\end{array}$ & Consumers & Smart phone adoption \\
\hline 25 & $\begin{array}{l}\text { Juaneda-Ayensa et } \\
\text { al. (2016) }\end{array}$ & Spain & Consumers & Omnichannel shopping \\
Koenig-Lewis et al. & France & Consumers & Mobile payments \\
\hline
\end{tabular}




\begin{tabular}{|c|c|c|c|c|}
\hline 27 & Lai et al. (2016) & $\begin{array}{l}\text { Hongkong, } \\
\text { China and USA }\end{array}$ & Students & Informal learning context \\
\hline 28 & $\begin{array}{l}\text { Lallmahomed et al. } \\
\text { (2013) }\end{array}$ & Malaysia & Students & Facebook usage \\
\hline 29 & $\begin{array}{l}\text { Morosan \& } \\
\text { DeFranco (2016b) }\end{array}$ & USA & Consumers & $\begin{array}{l}\text { Near Field Communication } \\
\text { Payments }\end{array}$ \\
\hline 30 & Nair et al. (2015) & Malaysia & Students & Lecture capturing system \\
\hline 31 & $\begin{array}{l}\text { Nguyen et al. } \\
(2014 a)\end{array}$ & Vietnam & Consumers & Cloud based E-learning \\
\hline 32 & $\begin{array}{l}\text { Nguyen et al. } \\
(2014 \mathrm{~b})\end{array}$ & Vietnam & Consumers & Cloud based E-learning \\
\hline 33 & $\begin{array}{l}\text { Oechslein et al. } \\
\text { (2014) }\end{array}$ & Germany & Students & $\begin{array}{l}\text { Social recommender } \\
\text { systems }\end{array}$ \\
\hline 34 & $\begin{array}{l}\text { Oliveira et al. } \\
\text { (2016) }\end{array}$ & Portugal & Consumers & Mobile payments \\
\hline 35 & $\begin{array}{l}\text { Pfeiffer et al. } \\
\text { (2016) }\end{array}$ & Germany & Consumers & $\begin{array}{l}\text { Wearable self-tracking } \\
\text { device }\end{array}$ \\
\hline 36 & $\begin{array}{l}\text { Raman \& Don } \\
\text { (2013) }\end{array}$ & Malaysia & Students & $\begin{array}{l}\text { Learning Management } \\
\text { System }\end{array}$ \\
\hline 37 & $\begin{array}{l}\text { Ramantoko et al. } \\
\text { (2015). }\end{array}$ & Indonesia & Consumers & Home Digital Services \\
\hline 38 & $\begin{array}{l}\text { Ramírez-Correa et } \\
\text { al. (2014) }\end{array}$ & Chile & Consumers & Mobile Internet \\
\hline 39 & $\begin{array}{l}\text { Salinas Segura \& } \\
\text { Thiesse (2015) }\end{array}$ & $\begin{array}{l}\text { Amazon } \\
\text { mechanical } \\
\text { Turk/Germany }\end{array}$ & Consumers & $\begin{array}{l}\text { Pervasive Information } \\
\text { Systems(Google glass) }\end{array}$ \\
\hline 40 & Slade et al. (2015a) & $\begin{array}{l}\text { United } \\
\text { Kingdom }\end{array}$ & Consumers & Proximity mobile payments \\
\hline 41 & Fard et al. (2016) & Malaysia & Male Consumers & $\begin{array}{l}\text { Purchase intention in Social } \\
\text { networking sites }\end{array}$ \\
\hline & Fard et al. (2016) & Malaysia & Female Consumers & $\begin{array}{l}\text { Purchase intention in Social } \\
\text { networking sites }\end{array}$ \\
\hline & Fard et al. (2016) & Malaysia & 18 to 24 Years & $\begin{array}{l}\text { Purchase intention in Social } \\
\text { networking sites }\end{array}$ \\
\hline & Fard et al. (2016) & Malaysia & $>24$ Years & $\begin{array}{l}\text { Purchase intention in Social } \\
\text { networking sites }\end{array}$ \\
\hline 42 & Wong et al. (2014) & Malaysia & Students & Mobile TV \\
\hline 43 & Wong et al. (2015b) & Malaysia & Consumers & Mobile learning \\
\hline
\end{tabular}

\section{References}

Ahn, M., Kang, J., \& Hustvedt, G. (2016). A model of sustainable household technology acceptance. International Journal of Consumer Studies, 40(1), 83-91.

Ain, N., Kaur, K., \& Waheed, M. (2016). The influence of learning value on learning management system use: An extension of UTAUT2. Information Development, 32(5), 1306-1321.

Alalwan, A. A. (2018). Investigating the impact of social media advertising features on customer purchase intention. International Journal of Information Management, 42, 65-77.

Alalwan, A. A., Dwivedi, Y. K., \& Rana, N. P. (2017). Factors influencing adoption of mobile banking by Jordanian bank customers: Extending UTAUT2 with trust. International Journal of Information Management, 37(3), 99-110.

Alalwan, A. A., Dwivedi, Y. K., Rana, N. P., Lal, B., \& Williams, M. D. (2015). Consumer adoption of Internet banking in Jordan: Examining the role of hedonic motivation, habit, self-efficacy and trust. Journal of Financial Services Marketing, 20(2), 145-157. 
Alalwan, A. A., Dwivedi, Y. K., \& Williams, M. D. (2016). Customers' intention and adoption of telebanking in Jordan. Information Systems Management, 33(2), 154-178.

Anandarajan, M., Igbaria, M., \& Anakwe, U. P. (2002). IT acceptance in a less-developed country: a motivational factor perspective. International Journal of Information Management, 22(1), 47-65.

Baabdullah, A. M., Alalwan, A. A., Rana, N. P., Kizgin, H., \& Patil, P. (2019). Consumer use of mobile banking (M-Banking) in Saudi Arabia: Towards an integrated model. International Journal of Information Management, 44, 38-52.

Baptista, G., Baptista, G., Oliveira, T., \& Oliveira, T. (2017). Why so serious? Gamification impact in the acceptance of mobile banking services. Internet Research, 27(1), 118139.

Baptista, G., \& Oliveira, T. (2015). Understanding mobile banking: The unified theory of acceptance and use of technology combined with cultural moderators. Computers in Human Behavior, 50, 418-430.

Brown, S. A., \& Venkatesh, V. (2005). A model of adoption of technology in the household: A baseline model test and extension incorporating household life cycle. Management Information Systems Quarterly, 29(3), 399-426.

Buettner, R. (2016). Getting a job via career-oriented social networking sites: the weakness of ties. 49th Hawaii International Conference on System Sciences (HICSS).

Carroll, J. M., \& Thomas, J. C. (1988). Fun. ACM SIGCHI Bulletin, 19(3), 21-24.

Chaouali, W., Yahia, I. B., \& Souiden, N. (2016). The interplay of counter-conformity motivation, social influence, and trust in customers' intention to adopt Internet banking services: The case of an emerging country. Journal of Retailing and Consumer Services, 28, 209-218.

Cvijikj, I., Kadar, C., Ivan, B., \& Te, F. (2015). Prevention or Panic: Design and Evaluation of a Crime Prevention IS. Paper presented at the 36th International Conference on Information Systems (ICIS).

Davis, F. D. (1989). Perceived usefulness, perceived ease of use, and user acceptance of information technology. MIS Quarterly, 13(3), 319-340.

Davis, F. D., Bagozzi, R. P., \& Warshaw, P. R. (1992). Extrinsic and intrinsic motivation to use computers in the workplace. Journal of applied social psychology, 22(14), 11111132.

Deci, E. L., \& Ryan, R. M. (1980). The empirical exploration of intrinsic motivational processes. In Advances in Experimental Social Psychology ,13, 39-80.

Dernbecher, S., Beck, R., \& Weber, S. (2013). Switch to your own to work with the known: An empirical study on consumerization of IT. Paper presented at the The 19th Americas Conference on Information Systems (AMCIS).

Dwivedi, Y. K., Rana, N. P., Jeyaraj, A., Clement, M., \& Williams, M. D. (2017). Reexamining the Unified Theory of Acceptance and Use of Technology (UTAUT): Towards a Revised Theoretical Model. Information Systems Frontiers, 1-16. doi: 10.1007/s10796-017-9774-y

Dwivedi, Y. K., Shareef, M. A., Simintiras, A. C., Lal, B., \& Weerakkody, V. (2016). A generalised adoption model for services: A cross-country comparison of mobile health (m-health). Government Information Quarterly, 33(1), 174-187.

Dwivedi, Y. K., Tamilmani, K., Williams, M. D., \& Lal, B. (2014). Adoption of M-commerce: examining factors affecting intention and behaviour of Indian consumers. International Journal of Indian Culture and Business Management, 8(3), 345-360.

Dwivedi, Y.K., Wastell, D., Laumer, S., Henriksen, H.Z., Myers, M.D., Bunker, D., Elbanna, A., Ravishankar, M.N., Srivastava, S.C. (2015). Research on information systems failures and successes: Status update and future directions. Information Systems Frontiers, 17(1), 143-157.

Eden, D. (2002). From the editors. Academy of Management Journal, 45(5), 841-846. 
Escobar-Rodrguez, T., Carvajal-Trujillo, E., \& Monge-Lozano, P. (2014). Factors that influence the perceived advantages and relevance of Facebook as a learning tool: An extension of the UTAUT. Australasian Journal of Educational Technology, 30(2), 136151.

Escobar-Rodríguez, T., \& Carvajal-Trujillo, E. (2014). Online purchasing tickets for low cost carriers: An application of the unified theory of acceptance and use of technology (UTAUT) model. Tourism Management, 43, 70-88.

Field, A. P. (2001). Meta-analysis of correlation coefficients: a Monte Carlo comparison of fixed-and random-effects methods. Psychological methods, 6(2), 161-180.

Gao, S., Krogstie, J., \& Yang, Y. (2015a). Differences in the adoption of smartphones between middle aged adults and older adults in China. Paper presented at the International Conference on Human Aspects of IT for the Aged Population.

Gao, Y., Li, H., \& Luo, Y. (2015b). An empirical study of wearable technology acceptance in healthcare. Industrial Management \& Data Systems, 115(9), 1704-1723.

Glass, G. V. (1976). Primary, secondary, and meta-analysis of research. Educational Researcher, 5(10), 3-8.

Grinstein, A. (2008). The relationships between market orientation and alternative strategic orientations: A meta-analysis. European Journal of Marketing, 42(1/2), 115-134.

Gsmaintelligence. (2017). Global Mobile Trends 2017. Retrieved from https://www.gsmaintelligence.com/research/?file=3df1b7d57b1e 63a0cbc3d585feb82d c2\&download. Last accessed $06^{\text {th }}$ June 2018

Hamari, J., \& Koivisto, J. (2015). Why do people use gamification services? International Journal of Information Management, 35(4), 419-431.

Hampton-Sosa, W. (2017). The impact of creativity and community facilitation on music streaming adoption and digital piracy. Computers in Human Behavior, 69, 444-453.

Herrero, Á., \& San Martín, H. (2017). Explaining the adoption of social networks sites for sharing user-generated content: A revision of the UTAUT2. Computers in Human Behavior, 71, 209-217.

Huang, K.-Y., \& Chuang, Y.-R. (2016). A task-technology fit view of job search website impact on performance effects: An empirical analysis from Taiwan. Cogent Business \& Management, 3(1), 1-18. doi:10.1080/23311975.2016.1253943

Hunter, J. E., \& Schmidt, F. L. (2000). Fixed effects vs. random effects meta-analysis models: Implications for cumulative research knowledge. International Journal of Selection and Assessment, 8(4), 275-292.

Hunter, J. E., Schmidt, F. L., \& Jackson, G. B. (1982). Meta-analysis: Cumulating research findings across studies (Vol. 4): Sage Publications, Inc.

Inc, D. R. (1988). Macintosh or MS-DOS: A synopsis of what MIS managers and other professionals in Fortune 1000 companies have to say.

Ismagilova, E., Dwivedi, Y. K., Slade, E., \& Williams, M. D. (2017). Electronic word of mouth (eWOM) in the marketing context: A state of the art analysis and future directions: Springer.

Järvinen, J., Ohtonen, R., \& Karjaluoto, H. (2016). Consumer Acceptance and Use of Instagram. Paper presented at the 49th Hawaii International Conference System Sciences (HICSS).

Kapoor, K. K., Tamilmani, K., Rana, N. P., Patil, P., Dwivedi, Y. K., \& Nerur, S. (2017). Advances in Social Media Research: Past, Present and Future. Information Systems Frontiers, 1-28.

King, W. R., \& He, J. (2005). Understanding the role and methods of meta-analysis in IS research. Communications of the Association for Information Systems, 16(1), 665-686.

King, W. R., \& He, J. (2006). A meta-analysis of the technology acceptance model. Information \& Management, 43(6), 740-755. 
Koenig-Lewis, N., Marquet, M., Palmer, A., \& Zhao, A. L. (2015). Enjoyment and social influence: predicting mobile payment adoption. The Service Industries Journal, 35(10), 537-554.

Koohikamali, M., Gerhart, N., \& Mousavizadeh, M. (2015). Location disclosure on LB-SNAs: The role of incentives on sharing behavior. Decision Support Systems, 71, 78-87.

Koohikamali, M., Peak, D. A., \& Prybutok, V. R. (2017). Beyond self-disclosure: Disclosure of information about others in social network sites. Computers in Human Behavior, 69, $29-42$.

Kourouthanassis, P., Boletsis, C., Bardaki, C., \& Chasanidou, D. (2015). Tourists responses to mobile augmented reality travel guides: The role of emotions on adoption behavior. Pervasive and Mobile Computing, 18, 71-87.

Kulviwat, S., Bruner, I., Gordon, C., Kumar, A., Nasco, S. A., \& Clark, T. (2007). Toward a unified theory of consumer acceptance technology. Psychology \& Marketing, 24(12), 1059-1084.

Lai, C., Wang, Q., Li, X., \& Hu, X. (2016). The influence of individual espoused cultural values on self-directed use of technology for language learning beyond the classroom. Computers in Human Behavior, 62, 676-688.

Lallmahomed, M. Z., Rahim, N. Z. A., Ibrahim, R., \& Rahman, A. A. (2013). Predicting different conceptualizations of system use: Acceptance in hedonic volitional context (Facebook). Computers in Human Behavior, 29(6), 2776-2787.

Leong, C., Tan, B., Xiao, X., Tan, F. T. C., \& Sun, Y. (2017). Nurturing a FinTech ecosystem: The case of a youth microloan startup in China. International Journal of Information Management, 37(2), 92-97.

Lu, J., Liu, C., \& Wei, J. (2017). How Important Are Enjoyment and Mobility for Mobile Applications? Journal of Computer Information Systems, 57(1), 1-12.

Ma, Q., \& Liu, L. (2004). The technology acceptance model: A meta-analysis of empirical findings. Journal of Organizational and End User Computing (JOEUC), 16(1), 59-72.

Mahfuz, M. A., Hu, W., \& Khanam, L. (2016). The Influence of Cultural Dimensions and Website Quality on m-banking Services Adoption in Bangladesh: Applying the UTAUT2 Model Using PLS. Paper presented at the WHICEB.

Makki, T. W., DeCook, J. R., Kadylak, T., \& Lee, O. J. (2018). The Social Value of Snapchat: An Exploration of Affiliation Motivation, the Technology Acceptance Model, and Relational Maintenance in Snapchat Use. International Journal of Human-Computer Interaction, 34(5), 410-420.

Martins, C., Oliveira, T., \& Popovič, A. (2014). Understanding the Internet banking adoption: A unified theory of acceptance and use of technology and perceived risk application. International Journal of Information Management, 34(1), 1-13.

Morosan, C. (2016). An empirical examination of US travelers' intentions to use biometric egates in airports. Journal of Air Transport Management, 55, 120-128.

Nistor, N., Baltes, B., Dascălu, M., Mihăilă, D., Smeaton, G., \& Trăuşan-Matu, Ş. (2014). Participation in virtual academic communities of practice under the influence of technology acceptance and community factors. A learning analytics application. Computers in Human Behavior, 34, 339-344.

Oliveira, T., Thomas, M., Baptista, G., \& Campos, F. (2016). Mobile payment: Understanding the determinants of customer adoption and intention to recommend the technology. Computers in Human Behavior, 61, 404-414.

Qasim, H., \& Abu-Shanab, E. (2016). Drivers of mobile payment acceptance: The impact of network externalities. Information Systems Frontiers, 18(5), 1021-1034.

Raman, A., \& Don, Y. (2013). Preservice teachers' acceptance of learning management software: An application of the UTAUT2 model. International Education Studies, 6(7), 157-164. 
Ramantoko, G., Putra, G., Ariyanti, M., \& Sianturi, N. V. (2015). Early Adoption Characteristic of Consumers': A Behavioral Intention to Use Home Digital Services in Indonesia. Paper presented at the 3rd International Seminar and Conference on Learning Organization (ISCLO 2015).

Ramírez-Correa, P. E., Rondán-Cataluña, F. J., \& Arenas-Gaitán, J. (2014). An empirical analysis of mobile Internet acceptance in Chile. Information Research, 19(3), 113-134.

Rana, N. P., Dwivedi, Y. K., \& Williams, M. D. (2015). A meta-analysis of existing research on citizen adoption of e-government. Information Systems Frontiers, 17(3), 547-563.

Robin, C. F., McCoy, S., \& Yáñez, D. (2016). Surfing the Social Networks. Paper presented at the International Conference on Social Computing and Social Media.

Sabherwal, R., Jeyaraj, A., \& Chowa, C. (2006). Information system success: individual and organizational determinants. Management science, 52(12), 1849-1864.

Schmidt, F. L. (1992). What do data really mean? Research findings, meta-analysis, and cumulative knowledge in psychology. American Psychologist, 47(10), 1173-1181.

Segura, A. S., \& Thiesse, F. (2015). Extending UTAUT2 to Explore Pervasive Information Systems. Paper presented at the Twenty-Third European Conference on Information Systems (ECIS),, Münster, Germany.

Shareef, M. A., Dwivedi, Y. K., Kumar, V., \& Kumar, U. (2017). Content design of advertisement for consumer exposure: Mobile marketing through short messaging service. International Journal of Information Management, 37(4), 257-268.

Shaw, N., \& Sergueeva, K. (2019). The non-monetary benefits of mobile commerce: Extending UTAUT2 with perceived value. International Journal of Information Management, 45, 44-55.

Singh, H., Kar, A. K., \& Ilavarasan, P. V. (2017). Assessment of e-governance projects: an integrated framework and its validation. Paper presented at the Proceedings of the Special Collection on eGovernment Innovations in India.

Singh, H., Kar, A. K., \& Ilavarasan, P. V. (2019). Adoption of e-Government Services: A Case Study on e-Filing System of Income Tax Department of India. In Operations Research in Development Sector (pp. 109-123): Springer.

Singh, M., Sahu, G. P., Dwivedi, Y., Rana, N., \& Tamilmani, K. (2018). Success Factors for e-Court Implementation at Allahabad High-Court. Paper presented at the TwentySecond Pacific Asia Conference on Information Systems Japan.

Slade, E., Williams, M., Dwivedi, Y., \& Piercy, N. (2015a). Exploring consumer adoption of proximity mobile payments. Journal of Strategic Marketing, 23(3), 209-223.

Slade, E. L., Dwivedi, Y. K., Piercy, N. C., \& Williams, M. D. (2015b). Modeling consumers' adoption intentions of remote mobile payments in the United Kingdom: extending UTAUT with innovativeness, risk, and trust. Psychology \& Marketing, 32(8), 860-873.

Tamilmani, K., Rana, N. P., \& Dwivedi, Y. K. (2017). A Systematic Review of Citations of UTAUT2 Article and Its Usage Trends. Paper presented at the Conference on eBusiness, e-Services and e-Society, IIT Delhi, India.

Tamilmani, K., Rana, N. P., \& Dwivedi, Y. K. (2018a). Generalisability Of UTAUT2 Theory, Testing Efficacy In Marketing Domain: A Systematic Review And Meta-Analysis. Paper presented at the European Marketing Academy(EMAC), University of Strathclyde, Glasgow.

Tamilmani, K., Rana, N. P., \& Dwivedi, Y. K. (2018b). Mobile Application Adoption Predictors: Systematic Review of UTAUT2 Studies Using Weight Analysis. Paper presented at the Conference on e-Business, e-Services and e-Society.

Tamilmani, K., Rana, N. P., \& Dwivedi, Y. K. (2018c). Use of 'Habit' is Not a Habit in Understanding Individual Technology Adoption: A Review of UTAUT2 based Empirical Studies. Paper presented at the IFIP 8.6 Conference on Smart Working, Living and Organising, Portsmouth. 
Tamilmani, K., Rana, N. P., Dwivedi, Y. K., Sahu, G. P., \& Roderick, S. (2018d). Exploring the Role of 'Price Value' for Understanding Consumer Adoption of Technology: A Review and Meta-analysis of UTAUT2 based Empirical Studies. Paper presented at the Twenty-Second Pacific Asia Conference on Information Systems Japan.

Tamilmani, K., Rana, N. P., Alryalat, M. A. A., Al-Khowaiter, W. A., \& Dwivedi, Y. K. (2018e). Social media research in the context of emerging markets: An analysis of extant literature from information systems perspective. Journal of Advances in Management Research, 15(2), 115-129.

Vallerand, R. J. (1997). Toward a hierarchical model of intrinsic and extrinsic motivation. In Advances in experimental social psychology (Vol. 29, pp. 271-360): Elsevier.

Van der Heijden, H. (2004). User acceptance of hedonic information systems. MIS Quarterly, $28(4), 695-704$.

Venkatesh, V. (1999). Creation of favorable user perceptions: exploring the role of intrinsic motivation. MIS Quarterly, 23(2), 239-260.

Venkatesh, V. (2000). Determinants of perceived ease of use: Integrating control, intrinsic motivation, and emotion into the technology acceptance model. Information Systems Research, 11(4), 342-365.

Venkatesh, V., \& Brown, S. A. (2001). A longitudinal investigation of personal computers in homes: adoption determinants and emerging challenges. MIS Quarterly, 25(1), 71-102.

Venkatesh, V., Morris, M. G., Davis, G. B., \& Davis, F. D. (2003). User acceptance of information technology: Toward a unified view. MIS Quarterly, 27(3), 425-478.

Venkatesh, V., Thong, J. Y., \& Xu, X. (2012). Consumer acceptance and use of information technology: extending the unified theory of acceptance and use of technology. MIS Quarterly, 36(1), 157-178.

Venkatesh, V., Thong, J. Y., \& Xu, X. (2016). Unified Theory of Acceptance and Use of Technology: A Synthesis and the Road Ahead. Journal of the Association for Information Systems, 17(5), 328-376.

Williams, M. D., Rana, N. P., \& Dwivedi, Y. K. (2015). The unified theory of acceptance and use of technology (UTAUT): a literature review. Journal of Enterprise Information Management, 28(3), 443-488.

Wong, C.-H., Tan, G. W.-H., Tan, B.-I., \& Ooi, K.-B. (2015a). Mobile advertising: the changing landscape of the advertising industry. Telematics and Informatics, 32(4), 720 734.

Wong, C.-H., Wei-Han Tan, G., Loke, S.-P., \& Ooi, K.-B. (2014b). Mobile TV: a new form of entertainment? Industrial Management \& Data Systems, 114(7), 1050-1067.

$\mathrm{Wu}$, J., \& Du, H. (2012). Toward a better understanding of behavioral intention and system usage constructs. European Journal of Information Systems, 21(6), 680-698.

$\mathrm{Wu}$, J., \& Lederer, A. (2009). A meta-analysis of the role of environment-based voluntariness in information technology acceptance. MIS Quarterly, 33(2), 419-432.

Zhao, Y., Ni, Q., \& Zhou, R. (2017). What factors influence the mobile health service adoption? A meta-analysis and the moderating role of age. International Journal of Information Management, 43, 342-250. 